\title{
Analysis of Knowledge of Senior High School (SMA N) 2 Singaparna Students About Epidemiology of Sexual Transmitted Infections (STIs) and Lesbian, Gay, Bisexual, Transgender (LGBT) in 2019
}

\author{
$1^{\text {st }}$ Wuri Ratna Hidayani \\ Lecturer of Public Health \\ STIKes Respati \\ Cikunir KM 11 Singaparna Street \\ Tasikmalaya, Indonesia \\ wuri.ratnahidayani@gmail.com
}

\author{
$2^{\text {nd }}$ Haidir Syafrullah \\ Lecturer of Midwifery \\ STIKes Dharma Husada \\ Bandung, Indonesia
}

\author{
$3^{\text {rd }}$ Elly Satiyasih Rosali \\ Lecturer of Geografi \\ Siliwangi University \\ Tasikmalaya, Indonesia
}

\begin{abstract}
In 2012 there were 357 million cases of sexually transmitted infections in the world. In Indonesia in 2016 as many as 61 thousand cases, West Java was the highest rank of STI in 2012 In 2016 the highest prevalence of STIs was gonorrhea 3430 cases $^{1}$. Preliminary Study in December 2018 counseling guidance teacher stated that most of the knowledge of high school students did not yet understand the epidemiology of sexually transmitted infections (STIs) and LGBT. It is feared that students do not know the preventive risk of transmitting sexually transmitted infections and LGBT behavior. To determine of knowledge of Senior High School (SMAN) 2 Singaparna students about the epidemiology of STIs, risk factors for STIs and the danger of LGBT. observational study with a descriptive research design with qualitative methods. The sample of this study was students with a purposive sampling of 29 Senior High School Students in January 2019. Data collection using questionnaires and indepth interviews. The analysis used results of interviews and open questionnaires. Knowledge of Senior High School (SMAN) 2 Singaparna students about the epidemiology of STIs, students only know the STI disease agent, which is a virus. Risk factors that are known to students are behavior, sexual deviation and blood transfusion without screening. STI classification that students say the STI classification is HIV / AIDS. the majority of students mention the length of LGBT but some students who cannot mention the impact of LGBT and prevention LGBT.
\end{abstract}

Keywords-Knowledge students, Epidemiology, Sexual Transmitted Infections, LGBT

\section{INTRODUCTION}

In 2012 there were 357 million cases of sexually transmitted infections in the world [1]. Youth (aged 15-24 years old) are particularly vulnerable to STIs due to their high likelihood to engage in risky behaviors. The majority of youth are students, especially in developed countries. Therefore, educational institutions represent ideal settings to implement effective strategies to help reduce the STI burden and provide improved health to their students [2]. In 2009, the World Health Organization highlighted the importance of a comprehensive STDs control strategy, which includes the promotion and provision of prevention strategies, targeted community-based interventions, reliable data to guide the response, as well as effective clinical services for STD patients. Moreover, the World Health Organization emphasizes the value of knowledge and awareness of the population, as this promotes a drop in the rate of STD incidences and prevalence in the long-run [3]. According to WHO estimates, STIs have an annual incidence of 357 million cases among which chlamydia (131 million), gonorrhoea (78 million), syphilis (5.6 million) and trichomoniasis (143 million) [4]. In Indonesia in 2016 as many as 61 thousand cases, West Java was the highest rank of STI in 2012 in Bandung as many as 1,419 cases while in 2011 there were 141 cases. In 2016 the highest prevalence of STIs was gonorrhea in 3430 cases. According to the WHO report in 2015 there were 34 million people died of HIV / AIDS since AIDS was discovered, recorded in 2015 the incidence of AIDS there were 1.1 million people. In Indonesia the HIV prevalence in the young age group of 15-49 years is estimated to be around $0.27 \%$ among $237,500,000$ in 2012 with the cumulative number of HIV infections reported in Indonesia increasing 10-fold in 2006-2011 [5]. According to data from the Ministry of Women's Empowerment in 2014 there were 501,400 HIV / AIDS cases spread in 32 provinces and 300 
districts in Indonesia, at risk age is productive age in the 15-29 years age group. In 2014, West Java Province was ranked first in HIV / AIDS with 3,213 cases, DKI Jakarta 2,810 cases, East Java 2,753 cases, Papua 2,605 cases [6]. According to the 2015 Ministry of Health Information Data and Information The prevalence of HIV / AIDS is estimated at 36.7 million (34 million-39.8 million), an increase of 3.4 million compared to 2010 but a decrease in HIV / AIDS deaths, while the incidence of HIV / AIDS AIDS as many as 2.1 million people [7].

The knowledge of high school students about the epidemiology of sexually transmitted infections is very important in efforts to prevent and reduce the incidence of STIs. According to STI epidemiological surveillance in Barcelona in the age group of 15-29 years with the highest frequency of STI events, gonnorhoea in men is $21.5 \%$ and syphilis in women is $36.3 \%$ compared to HIV in males $13.0 \%$ and lymphogranuloma inguinale in female $19.4 \%$ [8]. At the high school level of education is very vulnerable to risk of sexually transmitted infections. This is proven by the results of epidemiological surveillance in Barcelona showing the highest level of high school education is the incidence of STIs, namely HIV and gonorrhea respectively 118 cases and 131 cases compared to the level of university education and basic education [8]. Deviant sexual behavior known as Lesbian, Gay, Bisexual and Transgender (LGBT) is increasing in Indonesia which increases the risk of sexually transmitted infections (STIs). Indonesia is a country that is intolerant of the LGBT phenomenon and is listed as having the highest number of deviant sexual orientations in the world after China, India, Europe, America. There are around $26.1 \%$ of Indonesia's population who say they dislike the LGBT community especially Moslems in Indonesia [9]. Several independent surveys state that Indonesia has 3\% of LGBT population or around 7.5 million people with LGBT of 250 million people in Indonesia [10].Based on the 2013 Integrated Biological and Behavioral Surveillance stated that HIV prevalence in injecting drug users (IDUs) was 39.2\%, men like men (MSM) was $12.8 \%$, transsexuals were $7.4 \%$, women direct sex workers (FSWs) ) by $7.2 \%$, Women indirect sex workers (WPSTL) by $1.6 \%$, Community-assisted residents (WBP) by $1.2 \%$, risti men by $0.2 \%$. In the STI group, the prevalence of syphilis in MSM was $11.3 \%$, transsexuals were $9.7 \%$, while the highest gonorrhea in WPSL was $32.2 \%$, transsexuals were $19.4 \%$, WPSTLs were $17.7 \%$. The highest prevalence of chlamydia in WPSL was $40 \%$, WPSTL was $30.8 \%$ [11]. Knowledge is very important for someone who can influence health behavior. According to H.L Bloom that behavior, environment, genetics and health services greatly affect the degree of public health. Preliminary Study in December 2018 counseling guidance teachers stated that most of the knowledge of high school students did not yet understand the epidemiology of sexually transmitted infections (STIs) and LGBT. It is feared that students do not know the preventive risk of transmitting sexually transmitted infections and LGBT behavior.

\section{METHODS}

This type of research is an observational study with a descriptive qualitative research design. The population in this study were all students of Senior High School (SMAN) 2 Singaparna in the 2018/2019 school year. The sample of this study was students of class XII by purposive sampling totaling 29 high school kids in January 2019. Data collection using questionnaires and in-depth interviews. When the study was conducted on the date. Place of research in Senior High School (SMA N) 2 Singaparna. Data analysis was carried out from information that was obtained at the stage of research data collection from the results of interviews and open questionnaires, this analysis used two variables namely STI epidemiology, STI risk factors, STI classification, and LGBT which included definitions, LGBT signs, impacts and prevention LGBT.

\section{RESULTS}

A. Overview of Knowledge Level of Senior High School (SMAN) Singaparna Student About Epidemiology of Sexually Transmitted Infectious and Dangers of LGBT

1. knowledge of STI epidemiology

Based on the results of the study note that the number of respondents was 29 students with a majority of 18 years. Interview results about the knowledge of epidemiology of sexually transmitted infections, students from 29 students answered the same as follows:

"Epidemiology of sexually transmitted infections caused (agents) by viruses, people at risk (hosts) are commercial sex workers, sexual deviations in good children, homosexuals or MSM (men like men), lesbians. The STI environment is largely by changing partner behavior, injecting drugs "(Senior High School (SMAN) 2 Singaparna Students). Based on the research results of 29 students, it can be seen that the students' knowledge about STI epidemiology is still limited, little is known about STI epidemiology from the agent aspect only fixated on HIV / AIDS which is transmitted by Viruses.

\section{2. knowledge of STI risk factors}

Students knowledge of STI risk factors based on interviews with 29 students stated the same as follows:

"Risk factors for sexually transmitted infections are partner changing behavior, drug abuse behavior such as injecting drugs, sexual deviations such as sodomy, rape, unsterile blood transfusion or virus contamination" (Senior High School (SMAN) 2 Singaparna Students). According to students' statements knowledge about STI risk factors is sufficient but there are still many STI risk factors. Risk factors that are known to students are behavior, sexual deviation and blood transfusion without screening. This shows that there is still limited student knowledge about STI risk factors.

\section{3. knowledge of STI classifications}

According to the results of interviews with 29 students the knowledge of the STI classification states that:

"Sexually transmitted infections are HIV / AIDS and uterine cancer. STI classification is HIV / AIDS, syphilis, and Gonorhoe" (Senior High School (SMAN) 2 Singaparna Student) 
Based on these student statements it can be seen that the lack of student knowledge about the classification of STIs. The STI classification that students know is HIV / AIDS, uterine cancer, syphilis and gonorrhoe.

B. Knowledge Images of Students Senior High School (SMAN) 2 Singaparna About the Dangers of LGBT

1. knowledge of lgbt definitions

Based on the results of the study it can be seen that students' knowledge of the definition of LGBT is mostly focused on the length of LGBT. Based on the results of research conducted at Senior High School (SMA N) 2 Singaparna it can be seen that the majority of respondents define LGBT by mentioning the length of LGBT. There are students who do not know the meaning of the extension. In addition there are those who explain about the definition of LGBT only mentioning psychological disorders and sexual orientation disorders

"LGBT is a case that is being widely discussed worldwide. LGBT is an extension of lesbi, gay, bisexual, transgender is a case of sexual deviations that is rife among men and women" (Senior High School (SMA N) 2 Singaparna Students).

Based on the results of interviews with students stated that LGBT is a deviation that violates norms and religion. According to students' statements, it has been mentioned in detail the length of LGBT and the meaning of the term LGBT according to the following information:

"LGBT (Lesbi, Gay, Bisexual, Transgender) is deviant behavior that violates religious norms. Lesbi is a lover of the same sex, namely women like women. Gay is a man who likes the same sex between men and men again. Bisexual is a lover of all types so like both between men and women. Transgender is someone who changes genitals such as women into men" (SMA N 2 Singaparna Students)

2. knowledge of the causes, impact and prevention of lgbt

On interviews with students knowledge about the causes, impacts and prevention of LGBT states that the causes of LGBT can be caused by multiple causes, especially in terms of getting along, the impact of LGBT causes the transmission of sexually transmitted diseases, transmission of social diseases and their prevention by strengthening faith and learning religion causing LGBT is a disorder sexual orientation that has an impact on moral damage, health. parenting style is wrong, degradation of faith has a damaging impact on the future and gets social sanctions. Prevention is to strengthen faith. the causes of LGBT because they live too long and only have sex with one another have an impact on the nation's moral damage. the cause of LGBT is a social error that impacts on increasing HIV disease, loss of generations due to same-sex marriage, social sanctions. because they like the equipment of women or men, tomboyish, because of a breakup. The impact of LGBT is that it can transmit disease, can affect others, can result in extinction in humans because there is no marriage between women and men, causing shame to the family. the causes of LGBT are environmental factors that are not good, wrong parenting, lack of faith, for women the emergence of possessive feelings towards female friends and lack of interest.against the opposite sex.
Prevention by good religious education so that as a foundation of deviation and sexual orientation interviews can be seen that the causes of LGBT are as follows:

"There are so many causes of LGBT not only a matter of lack of faith but because of education and the surrounding environment, not a few LGBT also occur because of the concern for someone and dissatisfaction with the nature that should be. The impact of LGBT on the surrounding environment that is contagious, LGBT can damage the nation's future impact on oneself that can be alienated by his friends or become material for bullying. LGBT can be prevented by several things including deepening the faith and piety, deepening knowledge about LGBT, knowing the impact of LGBT" (Senior High School (SMA N) 2 Singaparna Students).

Based on interviews conducted, it can be seen that the cause of LGBT is wrong association that affects moral damage so that the prevention is the right parenting and increasing faith according to the following information:

"The cause of LGBT is the association that causes LGBT, poor socialization of the community, loose parental supervision, environment, lack of confidence. The impact of LGBT, among others, causes the large number of LGBT communities, undermining the morale of the nation, can destroy the present and future generations. Prevention of LGBT, among others: Faith that must always be instilled early on. Parents educate a child by instilling Islamic shari'ah, parents educate their children according to the sex of the child, that is from the game or by educating hard on boys, parents must instill good morale from an early age, love unfortunately from childhood is the base of the success of children in the future, parental supervision must be observant of the child's behavior or if there is a change in behavior in childrens" (Senior High School (SMA N) 2 Singaparna Students)

\section{DISCUSSION}

\section{A. Knowledge of STI epidemiology}

Epidemiology of sexually transmitted infections is an epidemiology that discusses a class of infectious diseases or infections that are transmitted mainly through sexual contact from person to person through the penis, vagina, anal, and oral. In addition, transmission can occur congenitally, from mother to fetus during the womb or at birth, through blood products or tissue transfer that has been contaminated, and through medical devices [12]. Various types of STI diseases include gonorrhea, chlamidiosis, lymphogranuloma venereum, Chancroid, Granuloma inguinale (donovanosis), non-gonorrhea urethritis, non-gonococcus urethritis, HIV / AIDS, Herpes simplex, genital warts, trichomoniasis, candidiasis, glandular urethritis, non-gonococcus urethritis, HIV / AIDS, herpes simplex, genital warts, trichomoniasis, candidiasis, mites, scabies (scabies) [13].LGBT is very closely related to the increasing prevalence of STIs. STI is the impact of sexual deviant behavior, partner changing behavior, homosexual, risky sexual behavior. In accordance with research Sevelius (2009) states that the prevalence of STIs increases as much as $25.2 \%$ through risky sexual behavior carried out repeatedly without 
protection [14]. Based on the research results of 29 students, it can be seen that the students' knowledge about STI epidemiology is still limited, only a little is known about STI epidemiology from the agent aspect only fixated on HIV / AIDS which is transmitted by viruses. Apart from environmental factors, most respondents answered only at risky sexual behavior. STI disease agents are very diverse can be caused by bacteria, viruses, parasites, lice, and fungi. According to the Ministry of Health (2016), STI agents caused by bacteria include syphilis, chancroid, granuloma inguinale, lymphogranuloma inguinale, trichomoniasis. STI agents caused by viruses include HIV / AIDS, herpes. IMS agents that are caused by parasites such as fungus namely candidiosis [7]. While the agents caused by lice are Ptirus pubis and scabies. Environmental factors affecting STI are very complex multiple causation, including biological environment, is virulence of viruses, population density; Behavioral and social environment influencing personal hygiene such as students can be caused by a lack of personal hygiene habits changing clothes, bathing habits, changing sanitary napkins during menstruation, cleaning habits in the female area, habits using feminine cleaning fluids made from chemicals, sprinkling habits talcum powder in the intimate area, the habit of lending each other underwear, scratching the itchy female part that eventually occur lesions.

In addition, environmental factors that influence STI are sexual deviant behavior in children by fedophiles such as sodomy; low socioeconomic factors that cause prostitution, high socioeconomic with the degradation of the faith so that online prostitution occurred with tens of millions of rupiah; socio-cultural factors such as weak customs and religious beliefs, political factors such as weak laws, genetic factors such as a mother who is pregnant and suffering from herpes will pass on to her child during childbirth by normal delivery, or a syphilis pregnant mother will pass on to her child congenitally. Based on students' statements of knowledge about STI risk factors is sufficient but there are still many STI risk factors. Risk factors that are known to students are behavior, sexual deviation and blood transfusion without screening. This shows that there is still limited student knowledge about STI risk factors. Risk factors for STIs include low knowledge, risky sexual behavior, personal hygiene, promiscuity, socioeconomic level, injecting drug abuse, blood transfusion without screening, sexual deviations, stress. In line with research Masni (2016) states that the risk factors associated with STIs are risk behavior, the role of health workers and the role of information media. According to the student's statement it can be seen that the lack of students' knowledge about STI classification. The STI classification that students know is HIV / AIDS, uterine cancer, syphilis and gonorrhea. HIV / AIDS, syphilis and gonorrhea are STIs, while uterine cancer is a non-communicable disease not STIs [15]. According to the classification theory the IMS is very diverse. Various types of STI diseases include gonorrhea, chlamidiosis, lymphogranuloma venereum, Chancroid, Granuloma inguinale (donovanosis), nongonorrhea urethritis, non-gonococcus urethritis, HIV/AIDS, Herpes simplex, genital warts, trichomoniasis, candidiasis, glandular urethritis, non-gonococcus urethritis, HIV / AIDS, herpes simplex, genital warts, trichomoniasis, candidiasis, mites, scabies (scabies) [7]. Based on students' exposure to STI epidemiology knowledge there needs to be an increase in health promotion to high school students to increase student knowledge of STI epidemiology. Health promotion is one way to prevent diseases and health problems or five levels of prevention. Health workers need to visit regularly to conduct information about STIs as well as screening STIs for screening, separating the diseased from a healthy group of people, for example there are students diagnosed with chlamidiosis, trichomoniasis, ptirus pubis or scabies for immediate treatment (early diagnosis) aims do not continue in advanced disease.

There is a need for motivation from teachers to continue to improve knowledge about the epidemiology of STI through health seminars in schools, increase interest in reading high school students, youth writing competitions about STIs, holding health screening for high school students aiming to increase student knowledge and improve healthy behavior, healthy personal hygiene in students, students can also avoid risky behavior, so as not exposed to STI disease. Sex education is compulsory in several countries; however, there are still countries, such as Saudi, that have not yet applied such educational material at any education level. There was some effort and campaigns within the last few years to educate young students, to protect themselves against sexual and behavioral abuse; however, the need to implement educational programs within curriculum remains at high importance educating student example courses about epidemiology STI [4]. According to the research of Bello (2020) states that knowledge about STIs is very important because the data of knowledge in the community including the age group 1529 years as a basis for information in interventions to control the prevalence of STIs by means of preventive promotive efforts to increase knowledge for example by promoting the health of STI epidemiology [16]. Zin's research (2019) states that knowledge of STIs is very important to reduce STI transmission. The high prevalence of STIs such as HIV, gonorrhea, and syphilis one of the risk factors is knowledge [17]. To increase the knowledge of STI, it can be done through various ways, namely through health promotion from the internet, television, radio. The role of parents is also very important in providing sexual education. Knowledge enhancement is expected to reduce transmission of STIs by knowing safe sex and transmission of mother to her child during pregnancy [17]. Nguyen research (2019) states that knowledge about STI causes risks in transmission of STI, the highest level of knowledge about STIs in Vietnam was Syphilis $(57,8 \%)$ while the least was HIV $(57,6 \%)$ [18].

B. Knowledge of LGBT

Based on interviews with 29 high school students most of them have not been able to explain the definition of LGBT, the causes, impacts and prevention of LGBT this shows the limitations of high school students' knowledge about the definition, causes, impacts and prevention of LGBT. Most students only answer the length of LGBT by not being able to explain the definition one by one the term 
LGBT. According to students' interviews, students only explained that LGBT was caused by promiscuity, wrong parenting, lack of faith without explaining in detail one by one the causes of lesbian, gay, bisexual and transgender people. The interview results also illustrate the difficulties students have when asked about LGBT prevention. This is due to the fact that knowledge is still low among students. There is a need to increase student knowledge in increasing knowledge about the definition, causes, impacts and prevention of LGBT. Increasing the role of teachers in motivating students, especially Guidance Counseling (BK) teachers to continue to socialize the importance of students in understanding about LGBT, the role of homeroom teachers and subject teachers as well as to participate in socializing about the dangers of LGBT, the role of religious teachers also continues to be improved to guide students in increasing faith and piety so as to provide a firm foundation with a strong religious provision. The principal's policy is also very important to create a religious school for the inculcation of religious values for students so that students are not easily influenced by distorted thinking that drags on behavior that violates the norm. Student activities such as OSIS, Boy Scouts, PMR, nature lovers, theater, mosque youth, are expected to educate students to increase knowledge about the dangers of LGBT, vigilance in choosing relationships, be careful in choosing friends on social media and smart in using technology such as social media and internet. Besides the good family and environmental factors for students also determine student personality and increase student knowledge. Parental supervision needs, religious education in the family to be continuously improved as a good mental and moral defense.Kasboll research (2019) states that in the implementation of protocols for child welfare in terms of sexuality that is holding LGBT colsultation grups with officials in charge of reproductive health about STI epidemiology, the danger of LGBT, LGBT colsultation group with a peer approach, the existence of foster mother about reproductive health in schools [19]. Martos (2017) states in the context of overcoming LGBT in the United States especially in adolescents namely by organizing 200 helath service units for people with LGBT [20]. This needs to be adopted in Indonesia by paying attention to LGBT people especially in students of Senior High School with improved helath service such as the dissemination of information about the danger that LGBT has an extreme impact on teenagers being able to commit suicide. According to interviews with 29 SMA N 2 Singaparna students, the majority stated that students' knowledge of the impact of LGBT was the increasing prevalence of STIs such as HIV / AIDS, Syphilis, Gonorhoe, Herpes.

This is in accordance with research Sevelius (2009) states that STI transmission generally occurs due to risky behavior, so that individuals who are susceptible to infection with sexual behavior by changing partners, sexual deviations will easily cause infection with STI. The prevalence of STIs increased by $25.2 \%$ through risky sexual behavior without protection. frequency repeatedly [14]. The impact of LGBT is not only in terms of health as explained by Senior High School (SMA N) 2 Singaparna students, but the various impacts that can arise from LGBT are that it can damage the family order for those who are married there is an increase in divorce rates, transmission of STIs to family members, exclusion from families, contrary to nature humans so that there is a psychological impact that is not calm, feeling guilty, confusion and low self-esteem. This is consistent with the research of Haas, et al (2011) on studies of suicide risk factors caused by LGBT states in the United States that based on a survey of 34 respondents living in various countries people who engage in same-sex marriage have the potential to experience anxiety, mental disorders trigger for suicide compared to heterosexual couples [21]. Heterosexual couples have a protective factor against mental disorders. There are reports in the United States that men who are married to men or gay after age 18 have a six times greater chance of suicide attempts. This is different in heterosexual couples. Gay, bisexual men in the United States around 12\% reported lifetime suicide attempts among adult men as a whole [21]. The majority of students' knowledge about LGBT prevention cannot explain how to prevent LGBT. Some students explained the prevention of LGBT by increasing faith and piety to Allah SWT, multiplying dhikr to Allah SWT, correct parenting, good relationships. This is in accordance with research Dacholfany (2016) states LGBT anticipation by raising awareness for LGBT perpetrators or strengthening faith by asking forgiveness for mistakes and sins committed as well as by making the obedience of the nation [22]. According to Research Nizham (2009) states that the anticipation of LGBT by way of Government by reviewing the laws and regulations of article 292 of the Criminal Code that gives freedom to practice the same sexual relations; Indonesian people filed a judicial review suit against the Criminal Code articles which gave way to the occurrence of crimes in the sexual field [22].

\section{CONCLUSION}

The knowledge SMA N 2 Singaparna students of STI epidemiology, namely students only know the STI disease agent, which is a virus, whereas STI agents vary, including viruses, bacteria, parasites, fungi. Risk factors that are known to students are behavior, sexual deviation and blood transfusion without screening. The STI classification that students know only mentions the STI classification as HIV / AIDS. Only 1 person mentioned HIV / AIDS, uterine cancer, syphilis and gonorrhea. The knowledge of SMA N 2 Singaparna students about the dangers of LGBT namely the majority mentioning the length of LGBT without knowing the meaning of the terms from LGBT, students' knowledge of the causes only mentions wrong patterns of care, lack of faith, association even though there are still many factors causing LGBT.

\section{ACKNOWLEDGMENTS}

We thank to STIKes Respati, STIKes Dharma Husada Bandung and Universitas Siliwangi for providing funding for this research. Thanks also students all parties involved in this research. 


\section{REFERENCES}

[1] Kemenkes RI. "Pedoman Nasional Penanganan Infeksi Menular Seksual". Direktorat Jenderal Pengendalian Penyakit dan Penyehatan Lingkungan. (Jakarta: Dirjen P2PL). 2011

[2] Soe, N M K, Bird Y,Schwandt M , Moraros, J. "STI Health Disparities: A Systematic Review and Meta-Analysis of the Effectiveness of Preventive Interventions in Educational Settings". International Journal of Environmental Research and Public Health Vol 15, No. 2819. Canada. pp1-17.2018.

[3] Albanghali M A, Othman A B A. "Cross-Sectional Study on the Knowledge of Sexually Transmitted Diseases among Young Adults Living in Albaha", Saudi Arabia, International Journal of Environmental Research and Public Health Vol 17, No. 1872. Saudi Arabia..pp 1-10. 2020.

[4] Visalli G, Osenza1 C, Mazzù1 F, Bertuccio1 MP, Spataro1 P, Pellicanò G F, Di pietro1, Picerno1 I, a Facciolà A. "Knowledge of Sexually Transmitted Infections and Risky Behaviours: A Survey Among High School and University Students". Journal Prev Med HYG 2019; Vol 60: No. E84-E92. (Italy: Journal Prev Med) pp 85-92. 2019

[5] Najmah.” Epidemiologi Penyakit Menular". (Trans Info Media. Jakarta). 2015

[6] Kementerian Pemberdayaan Perempuan dan Perlindungan Anak Republik Indonesia. "Kasus HIV/AIDS di Indonesia Meroket". Jakarta. 2016

[7] Kemenkes RI. "Modul Pelatihan Konseling dan Tes Sukarela HIV untuk Konselor Profesional". Direktorat Jenderal Pelayanan Medik dan Direktorat Jenderal Pemberantasan Penyakit Menular dan Penyehatan Lingkungan. Jakarta. 2015

[8] Sentís A, et al. "Sexually transmitted infections in young people and factors associated with HIV coinfection: an observational study in a large city". British Medical Journal Open 2019; Vol 9:No.e027245. (Canada:BMJ). pp 1-7. 2018

[9] Rehman J, Polymenopou E. "Is Green a Part of the Rainbow? Sharia, Homosexuality and LGBT Rights in the Muslim World". Fordham International Law Journal. Volume 37, Issue 12013 Article 7. pp 38-39. 2013

[10] Sujana, I Nyoman; Setyawati, Komang; Ujanti, Ni Made Puspasutari. "The Existence of The Lesbian, Gay, Bisexual and Transgender (LGBT) Community in The Perspective of a State Based on Pancasila". (Yogyakarta :Faculty of Law Universitas Gadjah Mada) MIMBAR HUKUM Volume 30, Nomor 1, Februari 2018, Halaman 127-139.2018

[11] Kemenkes RI. "Surveilens Terpadu Biologis dan Perilaku Tahun 2010". Direktorat Jenderal Pengendalian Penyakit dan Penyehatan Lingkungan. Jakarta. 2011
[12] Hakim, L. "Epidemiologi Infeksi Menular Seksual. Infeksi Menular Seksual". Edisi Keempat.Jakarta: Balai Penerbit Fakultas Kedokteran Universiatas Indonesia. 2009

[13] Chin, James. "Control of Comunicable Disease Manual". California University. America Public Health Association (APHA). 2000

[14] Sevelius. "There's No Pamphlet for the Kind of Sex I Have: HIVRelated Risk Factors and Protective Behaviors Among Transgender Men Who Have Sex with Non-Transgender Men" $J$ Assoc Nurses AIDS Care. 2009 ; 20(5): 398-410. San Fransisco. Pp 1-12.2009

[15] Masni; Nurdiana, Lante ;Arsin, Arsunan. "Faktor Risiko Kejadian Infeksi Menular Seksual di Puskesmas Kalumata Kota Ternate". (Universitas Hasanudin. Jurnal MKMI), Vol.12 No. 4, Desember 2016. 2016

[16] Bello I O M, Fagbamigbe AF. "Association between Knowledge of Sexually Transmitted Infections and Sources of the Previous Point of Care among Nigerians: Findings from Three National HIV and AIDS Reproductive Health Surveys". International Journal of Reproductive Medicine Volume 2020, Article ID 6481479, Nigeria. pp.1-11.2020

[17] Zin N M, Ishak I, Manoharan K. "Knowledge, attitude and practice towards sexually transmitted diseases amongst the inmates of women shelters homes at Klang Valley". BMC Public Health 2019, 19(Suppl 4):639.(Malaysia) pp 1-7.2019

[18] Nguyen SU, et al. "Lack of Knowledge About Sexual Transmitted Diseases (STDs) : Implications for STDs Prevention and Care Among Dermatology Patiens in an Urban City in Vietnam". Int.J.Environ. Res and Public Health. Vol 16 No 1080. pp 1-9. 2019

[19] Kasboll J, Paulsen V. "What is Known About The LGBTQ. Perspective in Child Welfare Service ? A Scoping Review Protocol”. BMJ Open. Vol 19, e 030675. pp 1-5. 2019

[20] Martos AJ, Wilson PA, Meyer IH. "Lesbian, gay, bisexual, and transgender (LGBT) health services in the United States: Origins, evolution, and contemporary landscape". PLoS ONE 12(7): e0180544.pp 1-18. 2017

[21] Haas, P et al. "Suicide and Suicide Risk in Lesbian, Gays, Bisexual, and Transgender Populations : Review and Recommendations." Journal of Homosexuality, 58:,pp10$51, .2011$

[22] Dacholfany,Ihsan; Khoirurrijal. "Dampak LGBT dan Antisipasinya di Masyarakat". Universitas Muhammadiyah Metro. NIZHAM,Vol. 05, No.01 Januari-Juni 2016 